\title{
EARLY DEVELOPMENT OF LAW AND EQUITY IN TEXAS
}

Burke in his Tract on the Popery Laws used the famous dictum:

"There are two, and only two, foundations of law, equity and utility."

In the Texas constitutional convention of 1845 , Thomas J. Rusk, the President of the Convention, paraphrased Burke's dictum and a text he had learned from Blackstone, in these words:

"When cases are to be decided, the eternal principles of right and wrong are to be first considered, and the next object is to give general satisfaction in the community."

He was advocating the employment of juries in equity cases. He urged that juries were better acquainted with the neighborhood and local conditions and circumstances than a chancellor and were generally as competent in suits in equity as in cases at law.

"And if twelve men determine against a man he does not go away abusing the organs of the law; he comes to the conclusion that he is in the wrong."

The proposed jury "innovation"-for it was an innovation in American jurisprudence-was not adopted without strong opposition, led by Chief Justice John Hemphill, who was Chairman of the Committee on Judiciary. In the course of his address on the subject, Judge Hemphill said:

"I cannot say that I am very much in favor of either chancery or the common-law system. I should much have preferred the civil law to have continued here in force for years to come. But inasmuch as the chancery system, together with the common law, has been saddled upon us, the question is now whether we shall keep up the chancery system or blend them together. If we intend to keep it up as it is known to the courts of England, of the United States, and of many of the states, we should oppose this

${ }^{2}$ Debates of the Texas Convention, Sess. July 28, 1845, Wm. F. Weeks, reporter, published by the authority of the convention (Houston, 1846) p. 274 . 
innovation; for I do not know of any alteration which could be a greater innovation."2

It will be necessary to recall that Texas declared its independence of Mexico on March 2, 1836 . The Constitution of the Republic of Texas, adopted on March 17,1836 , had provided ${ }^{3}$ that the Congress of the Republic should, by statute,

"introduce the common law of England, with such modifications as our circumstances, in their judgment, may require; and in all criminal cases, the common law shall be the rule of decision."

Until such time as the Congress should act in this regard, the "laws now in force in Texas" were to remain in force. The convention of 1836 broke up in disorder because of the shocking news of the fall of the Alamo and the invasion in force of the Mexican armies under the dictator, General Santa Anna. The first three congresses of the young Republic were engrossed largely with war legislation and political measures. On Jan. 20, 1840, the Fourth Congress in terms repealed "all the laws in force in this Republic prior to the first of Sept., I836," (i. e., the Mexican and Spanish law, including their common law, which is essentially Roman) and enacted that,

"the common law of England (so far as it is not inconsistent with the constitution or the acts of Congress now in force) shall, together with such acts, be the rule of decision in this Republic."

To the superficial observer, it might seem that in the contest on this remote frontier, the common law of England had gained the day over the civil law of Rome by reason of its greater virility and superior excellence. The colonists who were the fathers of the Republic of Texas were almost exclusively AingloSaxons, emigrants from the United States. They had come so recently under Mexican rule that they had neither time, facilities, nor inclination to become familiar with the Spanish language and the Spanish jurisprudence. Even the great Hemphill arrived in Texas as late as 1838 and acquired his knowledge of the Spanish law after that date. The wide expanse of country embraced in the Republic was very sparsely settled (the total

Ibid., pp. 27r-272.

- Art. IV, sec. r3. 
population.estimated at 20,000 ), the ox-cart was the usual means of transportation, Indian raids and Mexican incursions kept all the men virtually under arms, and the population were put to it to produce enough from the soil to keep alive. The simple fact is the early Texans neither gave nor could give any discriminating thought to their system of private law. This question was overshadowed by the greater public questions of the maintenance of independence, of annexation to the United States, of public land grants, and slavery. Besides, after their experience with Mexican cruelty and treachery, they had a natural suspicion of everything Mexican. Little wonder then that they abruptly rejected a system of law which was contained in a strange language and adopted a system with which they were familiar and the records of which were written in their own tongue. Had the local conditions been different then, it is possible Texas like Louisiana, could have been cited by Dr. Hannis Taylor as a striking corroboration of his thesis that,

"out of this fusion of Roman private and English public law there is arising throughout the world a new and composite state system, whose outer shell is English constitutional law, including jury trials in criminal cases, and whose interior code is Roman private law."4

It is a fact, however, that the Republic of Texas retained much of "the law as it aforetime was."

Having adopted the English common law as "the rule of decision," the Congress proceeded immediately by various statutory enactments to introduce important modifications of the common law. The Spanish community system of marital property rights was retained ${ }^{5}$; common-law rules as to succession were replaced by the civil-law rules ${ }^{8}$; the laws ${ }^{7}$ exempting property, including the homestead, from forced sale were taken from Spanish prototypes $^{8}$; the doctrines of the common law as to the estates arising

-Address before the Texas Bar Association, Proceedings (I9I4) p. 178.

-Act, Jan. 20, 1840 .

-Acts, Jan. 28, 1840, and Feb. 5, 1840 .

'Acts, Jan. 26, 1839, and Dec. 22, 1840 .

- Sayles, Early Laws of Texas, Introduction by Judge Willie, p. vi.

Dillon, Lawes and Jurisprudence of England and America, p. 360, writes: "The Republic of Texas passed the first homestead act in 1836 . It was the gift of the infant Republic of Texas to the world." The act of Jan. 26, 1830. is the first Texas legislation on the subject of the homestead. 
under a mortgage were entirely disregarded in the act of Feb. 5, I840, providing for the foreclosure of mortgages on real and personal property to satisfy "the lien created by the making of the mortgage"; the common-law rules as to the assignment of choses in action were abolished, as were also livery of seisin and common-law formalities in conveyancing. ${ }^{\circ}$ The act of Jan. 28, 1840, on wills retained the legitime and other features of the civil law; and most sweeping of all, the act of Feb. 5, 1840, expressly discarded the entire common-law system of pleading and provided,

- "that the proceedings in all civil suits shall, as heretofore, be conducted by petition and answer."10

In the interval between the enactment of the last mentioned act and the constitutional convention of 1845 , and in the face of the rejection of the common-law system of pleading, various statutes were enacted which referred in terms to the twofold jurisdiction of law and chancery. The very act of Feb. 5, I840, which preserved the former simple system of "petition and answer"-a system to which the artificial distinction between actions at law and in equity was wholly foreign - contains a clause providing that,

"in every civil suit in which sufficient matter of substance may appear upon the petition to enable the court to proceed upon the merits of the cause, the suit shall not abate for want of form; the court shall in the first instance endeavor to try each cause by the rules and principles of law; should the cause more properly belong to equity jurisdiction, the court shall, without delay, proceed to try the same according to the principles of equity."

This is a general exemption statute. The distinctive provision that the homestead owned by a married man could not be alienated by him without the consent of his wife first appeared in the constitution of 1845 by vote of the convention taken Aug. 5, 1845. It was debated in the convention as a matter of first impression.

- Act, Jan. 25, 1840.

${ }^{10}$ Later acts imported other elements of the civil law into the jurisprudence of Texas. We mention here as an example the act of Jan. 16, 1850, on the institution of a stranger as heir by adoption. Cf. Eckford et $u x v$. Know (I886) 67 Tex. 200, 204. It is not within the scope of this article to indicate all the numerous changes in the common law made by constitutional or statutory enactment, such as the abolition of dower, curtesy, primogeniture, estates tail, outlawry, trial by wager of battle, and wager of law, modifications as to the law of libel, etc. 
It was of this passage that the supreme court of the Republic said:

"A hundred judges, in almost any conceivable case, might differ in some degree as to its interpretation and exact function."11

They suggested that the district judge try each cause as at law, and "if he cannot succeed in the effort, then ascend the woolsack and chancel it." Other later statutes of the Republic recognized the distinction between actions at law and in equity and added to the perplexity of the-courts in their efforts to harmonize the civil and the common-law systems. ${ }^{12}$

This state of confusion called for fundamental treatment and the constitutional convention of 1845 supplied it. Upon the initiative of Hemphill and Rusk, the following provisions were written into the Constitution of Texas ${ }^{13}$ :

"The District Court shall have original jurisdiction... of all suits, complaints and pleas whatever, without regard to any distinction between law and equity, when the matter in controversy shall be valued at, or when the matter in controversy to, one hundred dollars exclusive of interest; and the said courts, or the judges thereof, shall have power to issue all writs necessary to enforce their own jurisdiction and give them a general superintendence and control over inferior jurisdictions." 14

"Whiting v. Turley (1842) Dallam (Tex.) 453.

23 The act of Feb. 5, 1840, to regulate proceedings in civil suits: sec. 2, as to costs "in any cause whether at law or equity."

The act of Feb. 5, 1840, on admission to the bar: sec. 2, admittance "to practice law in all the courts of law and equity."

The act of Jan. 25, I84r, to empower the judges of the district courts to submit issues of fact to a jury "in chancery cases," sec. 7.

The act of Feb. 5, I84r, on limitations: sec. 9, to the effect that "no bill of review shall be granted to any decree pronounced in equity after two years."

The act of Feb. 5, I84I, on sales by "courts of chancery."

These instances bear out Rusk's statement made in the convention of 1845: "Now, sir, the legislature has brought all things into confusion. Immediately after the revolution it was determined that one court should have jurisdiction over all cases, rejecting the useless distinction between law and equity, which has sincè grown up." Debates, p. 274.

"Art. IV, sec. 10.

"The proposal to create "separate chancery courts" was voted down in the convention. Journal of the Convention, p. rgr.

As to whether Texas or New York is entitled to the credit of being 
Despite this clear-cut abolition of a dual jurisdiction emigrant legislators and judges, steeped in the notions of their early legal training in common-law states and unfamiliar with the civil law, continued, as in the period from 1840 to 1845 , to introduce into the jurisprudence of Texas occasional fragments of the commonlaw system. ${ }^{15}$ This tendency disappeared as the indigenous system evolved and bench and bar became better acquainted with it. Apart from the special statutory action of trespass to try title for the recovery of land, it is recognized that there is in Texas but one form of civil action for the enforcement of private rights of whatever nature.

To abolish the common-law forms of action (including the chancery system) and yet retain the common law of England as "the rule of decision" is like trying to remove the motor nerves from a living being and leave the sensory nerves intact. The operation has not been successful in Texas.

Mr. Pomeroy asserts that the adoption of the system of code pleading,

"has not produced, and was not intended to produce, any alteration of, nor direct effect upon, the primary rights, duties and liabilities of persons, created by either department of the municipal law. . . The codes do not assume to abolish the distinctions between 'law' and 'equity' regarded as two complementary departments of the municipal law."16

The remark is not applicable to Texas. Texas has never been a "code state" nor a "quasi-code state."17 Its system of pleading arose out of the civil law as truly as did that of Louisiana.. ${ }^{38}$

the first state in the Union to adopt the blended system, see the Report of the Texas Bar Association Committee reproduced in (1896) 30 AM. L. REv. 813. Mr. Sayles' remark (ibid., p. 825) is suggestive: "As Texas never was a common-law state it cannot be said that she was the first to abolish the common-law system of practice, but it is the very highest evidence of the hard common sense of the pioneers of Texas that they retained these admirable features of the civil law."

${ }^{15}$ Cf. Blumberg v. Mauer (1873) 37 Tex. 2; Grassmeyer v. Beeson (1857) I8 Tex. 753, 766; New York \& Texas Land Company v. Hyland

(1894) 28 S. W. (Tex.) 206, 214

${ }^{10}$ Code Remedies (4th ed.) sec. 8.

"So classified by Mr. Hepburn in his valuable article, The Historical Development of Code Pleading in America and England in Select Essays in Anglo-American Legal History, Vol. II, p. 672.

John C. Townes, Pleading in the District and County Courts of Texas (2d ed.) pp. $84,85$. 
Moreover the constitutional abolition of the distinction between law and equity in the administration of justice in the Texas courts is not limited in terms or by right interpretation to the mere abolition of the distinction between legal and equitable procedure. ${ }^{19}$ Unfortunately, the opinions of the appellate courts still abound in loose references to "legal" titles and "equitable" titles (though the latter are said to be as "potent" as the former); the statutory action of trespass to try title is declared "essentially a legal action"; the plea of limitation under the statute is denominated a "legal defense," and so on. Over against these we get an occasional trenchant pronouncement like Hemphill's in Bennett v. Spillars. ${ }^{20}$

"If the rules and principles arising from the antagonisms of the common law and equitable jurisdictions were thoroughly extirpated from the mind the provisions of legislation and the decisions and practice of the courts would become more harmonious and more in accordance with our system of judicial procedure."

The English common-law system has been further mutilated in Texas by many statutory enactments and by the adoption of important fractions of a rival system so that its inner harmony is destroyed. Moreover, the Texas courts have not hesitated to declare the rules of the common law inapplicable to our conditions and inconsistent with our usages. ${ }^{21}$ Doubts have also recently arisen as to what is meant by the expression "the common law of England" in the Act of I840 quoted above. In The Indorsement Cases, ${ }^{22}$ decided in reconstruction days by a supreme court appointed by Major-General Griffin and commanding little respect in Texas, it was held that the law merchant constituted no part of the law of Texas because it was no part of the common law; i. e., the "ante-statute law of England." The Court of Criminal Appeals-the court of last resort in all criminal cases-by a vote

"Hamilton v. Avery (1857) 20 Tex. 6r2: "A subsisting equity, by the laws of this state that recognize no distinction between law and equity either in rights or their judicial preservation, confers a right of property by as strong a sanction as that which exists by a right purely legal."

(1852) 7 Tex. 600; 602.

n Stroud v. Springfield (1866) 28 Tex. 649, 666; Pace v. Potter (1893) 85 Tex. 473; Robertson $v$. State of Texas (I9Ir) 63 Ct. Cr. App. (Tex.) 216; Clarendon Land Co. v. McClelland Bros. (1893) 86 Tex. I79, 185 .

(1869) 3x Tex. 693. 
of two to one held in I9II that Texas has adopted also the English statutes in aid or amendment of the common law, passed before the emigration of our ancestors. ${ }^{23}$ In I9I3, the Supreme Court of Texas in holding that cohabitation was necessary to constitute a common-law marriage announced that,

"the common law of England adopted by the Congress of the Republic (of Texas) was that which was declared by the courts of the different states of the United States. . . . The decisions of the courts of those states determine what rule of the common law of England apply to this case. The effect of the act of 1840 was not to introduce and put into effect the body of the common law, but to make effective the provisions of the common law so far as they are not inconsistent with the conditions and circumstances of our people."24

Thus, the English decisions are not controlling as to the common law in Texas. The doctrine of stare decisis receives a body blow. A maze of sources is now to be drawn upon. The common law is not uniform throughout the states. Some have adopted the "ancient common law"; others the common law with reference to specific dates, with or without the statutes passed in amendment thereof; others, like Texas, without reference to any date. ${ }^{25}$ None have retained it without important modifications.

The upshot of the whole matter is that our complex jurisprudence in Texas has become a storehouse of authorities for any rule the courts deem suited to our peculiar conditions and to the exigencies of any particular case, so as to assure to the litigants substantial justice. The simplicity and flexibility of the Texas system of pleading, and the variety and complexity-not to say confusion-in the sources of our rules of substantive law have had the effect of freeing the Texas courts largely from the restraints of outworn distinctions and rigid classifications and reasonings of the remote past and lifting them into the clearer atmosphere of a living law which is more nearly the reflection of the economic and social ideals of our time. The jurisprudence of Texas to-day is essentially a system of Freirecht. Various factors have operated to make it such. It is a fatal mistake

Robertson v. State of Texas, supra.

"Grigsby v. Reib et al. (1913) 105 Tex. 597.

*Cf. (I916) I6 CoL. L. REv. 499, note. 
to assume that one can get a correct or comprehensive view of the jurisprudence of a state from the opinions of appellate courts alone. ${ }^{28}$

Early Texas precedents were made under conditions that gave limited opportunity for the examination of even secondary authorities and called for large creative freedom in the courts. ${ }^{27}$ Apart from Spanish authorities, Kent and Story, the decisions of the Louisiana courts were most frequently cited. The Louisiana civil code was admired and was freely drawn upon in the enactment of early laws. Its article 2 I certainly reflected the viewpoint of the early Texas decisions:

"In civil matters, where there is no express law, the Judge is bound to proceed and decide according to equity. To decide equitably an appeal is to be made to natural law and reason, or received usages, where positive law is silent."

We frequently find such expressions as these:

"The moral sense of what is enjoined by equity and good conscience must be exceedingly obtuse to suppose that such flagrant injustice would receive the slightest countenance from any judicatory however organized."28

And:

"It appears, then, that the liability of the defendant must result from the facts of the case, and not from the averments of the petition. If the possession of the defendant be wrongful, in the popular acceptation of the term, if it be inequitable and unconscientious . . . . he should in all events be responsible for the value of the property."20

I think we may safely say that apart from occasional lapses

\footnotetext{
${ }^{2}$ Quite recently the writer had the privilege of attending a banquet given in honor of a young lawyer who had just been appointed to the district court bench. Three members of the appellate courts in their addresses urgently advised the young jurist to pay little attention to the refinements of the law, to decide the causes submitted to him upon the broad basis of conscience and his conception of right and wrong, and they assured him he would be seldom reversed.

" On Dec. 18, 1837, Messrs. Jack and Kaufman were appointed by the Texas Congress to draft a code of laws, but the Republic had no law books and they made no progress. On Jan. 23, 1839, \$1,000.00 was appropriated for books for these commissioners. Whether they got the books or not is not known. They failed to submit a code.
}

${ }^{2}$ Hunt v. Turner (1853) 9 Tex. 385 .

Porter v. Miller (1852) 7 Tex. 468, 479, opinion by Hemphill. 
toward formalism, we have had in Texas from the very beginning a jurisprudence founded upon a "natural law with a variable content."

Besides the variety and richness of the sources of our jurisprudence, and the direction given by early precedents, the personnel of the judiciary has had much to do with the freedom of our jurisprudence from scholastic subtleties and slavish veneration for the ancient landmarks of the law. We certainly cannot complain of any Welffremdheit on the part of our judges. All judicial offices in Texas have generally been elective and for comparatively short terms. ${ }^{30}$. During the Republic the supreme court was composed of a chief justice, elected by the joint vote of both houses of Congress, and the several district judges as associate members. The judges of the Texas appellate courts have been drawn chiefly directly from the bar, at which they had achieved such success as brought them into prominence. Taken thus from the body of the people and dependent upon the suffrage of the people for re-election, it is unreasonable to suppose that the judges would consciously seek to bring about any estrangement between the people and the law. Furthermore, the overwhelming majority of the Texas judges, trial and appellate, have lacked and do lack a systematic law school education. Of the present membership of the two highest courts in Texas, not a single man has even attended a law school. After a painstaking search through available published and unpublished biographies, I find that only five of the sixty-six members of the Supreme Court of Texas graduated from a law school of any sort. Court opinions aside, not one has ever published a work of constructive legal scholarship. This is, of course, no reflection on their native ability nor necessarily on their learning. But it will not be held unbecoming in me, I am sure, to say that as a rule the opinions of the appellate courts in Texas do not disclose such an acquaintance with legal sistory, legal philosophy, and the science of jurisprudence, or such a degree of "discrimination in the use of the expository authorities" as one should expect from schooled jurists. It is vital that only

\footnotetext{
- The only exceptions occurred in the brief intervals $1845-1850$ and 1873-1876 when members of the supreme court were to be appointed by the Governor.

"Cf. Dean Wigmore's trenchant criticisms in The Qualities of Current Judicial Decisions (I9I5) 9 ILL. L. REv. 529.
} 
men of profound knowledge in legal science should be chosen to administer justice in a system characterized by such elasticity and freedom as ours. The appellate courts of Texas are now turning out about $I, 800$ published opinions a year-no other state has such an output. We have had-and are still having-a rough, blundering, frontier sort of justice. There has been much talk the past two years of "law reform" in Texas, which means more new and poorly considered legislation. But the heart of our jurisprudence is sound. If the time ever comes when the voices of our law professors will be effectively heard and respected in the forums of justice and the halls of legislation in this country, we may have a more constructive part in preserving the true principles of the law and keeping its evolution in right lines. Meantime, in harmony with or in defiance to "authority," we have the inspiring task of shaping the professional ideals and standards of the next generation of lawyers.

Grorge C. Butte.

Law Schoot, University of Texas. 